\title{
THE AGE OF MARRIAGE ON INTERDISIPLINARY ISLAMIC LAW PERSPECTIVES
}

\author{
Iwan Romadhan Sitorus ${ }^{1} \&$ Yusmita ${ }^{2}$ \\ 1,2 Fakultas Syariah IAIN Bengkulu \\ Jl. Raden Fatah Pagar Dewa Bengkulu \\ Email: 1iwanramadhan@iainbengkulu.ac.id; ²yusmitamag@gmail.com
}

\begin{abstract}
The Act No. 16 of 2019 is an amendment to The Act No. 1 of 1974 . The article 7 provides the age limit for each person who will marry at the age of 19 years for both men and women. The age limit given by the law does not look comprehensively in biological, sociological readiness, and so forth. The modified law should be able to produce the benefit of the husband and wife in fostering the household. This is because determining the age of marriage aims to maintain lineage, quality of offspring, patterns of family relationships, diversity in the family, and to prepare for maturity in the economy by taking into account various aspects such as psychological, sociological, and biological aspects. In this regard, the authors offer to reconstruct the provisions to 19 years for women and 21 years for men. This is based on consideration of the biological, psychological, and socio-cultural aspects of Indonesian society. By the age of 21 , men are considered to reach maturity in their attitude, able to act, and responsible for their actions. Whereas a 19-year-old woman is considered to be an adult and able to run a household life.
\end{abstract}

Keywords: Age of marriage, Islamic Law, Interdisciplinary

\begin{abstract}
Abstrak: Undang-undang Nomor 16 Tahun 2019 merupakan perubahan atas UU No 1 Tahun 1974. Pada pasal 7 memberikan batasan usia pada setiap orang yang akan melangsungkan perkawinan dengan usia 19 tahun bagi lakilaki dan 19 tahun bagi perempuan. Batasan usia yang diberikan oleh undang-undang tersebut tidak melihat secara komprehensif pada kesiapan biologis, sosiologis, dan lain-lain. Seharusnya undang-undang yang termodifikasi tersebut harus dapat mewujudkan kemaslahatan bagi pihak suami istri dalam membina rumah tangga. Ini karena penentuan usia perkawinan bertujuan untuk memelihara garis keturunan, kualitas keturunan, menjaga pola hubungan keluarga, menjaga keberagamaan dalam keluarga, dan mepersiapkan kematangan dalam ekonomi dengan memperhatikan berbagai aspek, baik aspek psikologis, sosiologis, dan biologis. Berkaitan dengan hal ini, maka penulis menawarkan untuk dilakukannya rekonstruksi kembali terhadap ketentuan tersebut menjadi 19 tahun bagi perempuan dan 21 tahun bagi laki-laki. Hal ini berdasarkan pertimbangan aspek kematangan biologis, psikologis, dan sosial budaya masyarakat Indonesia. Dengan usia 21 tahun tersebut, laki-laki dinilai mencapai kematangan dalam sikapnya, mampu dalam bertindak, serta bertanggung jawab terhadap perbuatannya. Sedangkan perempuan berusia 19 tahun dinilai sudah dewasa dan mampu untuk menjalankan kehidupan rumah tangga.
\end{abstract}

Kata kunci: Usia Perkawinan, Hukum Islam, Interdisipliner

\section{Introduction}

The complexity of Islamic family law issues, especially the age of marriage, is not only actual to be discussed, but also attracts the attention of the legislators, academics, and family observers with their respective perspectives. This is certainly unique to a modern Muslim-majority country with a national legal system such as Indonesia.
The efforts to accommodate or reconcile Islamic family law to suit the times are in order to create public $\operatorname{order}^{1}$ as one proof of

${ }^{1}$ Abdullah Saeed, Pemikiran Islam; Sebuah Pengantar, translated by Syamsuddin et al., (Yogyakarta: Baitul Hikmah Press, 2014), h. 103. This, at least in Anderson's note, in practical matters such as how Muslim-populated countries accommodate Islamic family law, is not an easy thing to do. Various ways have been carried out by Muslim countries in the world in creating their respective family law systems, ranging from implementing the sharia tradition 
this uniqueness. However, to examine the modernization of Islamic family law through the issue of marital age in Indonesia in its entirety, it cannot necessarily be released from the social history study of marriage legislation that has been deeply engraved in this country. In fact, the search for important aspects that occur behind the dynamics is a necessity.

It should be noted that the existence and legal entity of Islam, especially after Indonesia's independence, has an important position for the pace of development of its society going forward. This era was not only a starting point for the modernization of development in the early days of independence, but also very closely related to the process of legal struggle among Muslims when confronting the Islamic law with the state. ${ }^{2}$

The most prominent effort to implement Islamic law is in the field of family law, because it is the axis of sharia and considered as a benchmark and recognized by Islamic law in a country. ${ }^{3}$ Meanwhile, the post-independence life is faced with the demands of modernity, the tradition of Islamic law has still its own space when, at the same time, in tandem with world developments, especially in Indonesia. ${ }^{4}$ Ratno Lukito mentioned that after the abolition of feudalism, the state was placed as a source of law as well as a unifier for different legal traditions. This intervention gives rise to what is called the national legal system without prejudice to the existence of existing laws such as Islamic or customary law, so that the law becomes a

as a whole, leaving the shari'ah (secular) to compromising both. Therefore, judging from its style, it is not excessive if Indonesia is included in the latter category. See J.N.DAnderson, Hukum Islam di Dunia Modern, translated by Machnun Husein, (Yogyakarta: Tiara Wacana Yogya, 1994), h. 91.

${ }^{2}$ Mahsun Fuad, Hukum Islam Indonesia; Dari Nalar Parsipatoris hingga Emansipatoris, (Yogyakarta: LKiS, 2005), h. 5.

3 Toha Andiko, "Pembaruan Hukum Keluarga di Dunia Islam (Analisis Terhadap Regulasi Poligami dan Keberanjakannya dari Fiqh)", Nuansa: Jurnal Studi Islam dan Kemasyarakatan, Vol. 12, No. 2, Desember 2019, h. 3

4 Ratno Lukito, 'kata pengantar' dalam Maltuf Siroj, Pembaruan Hukum Islam di Indonesia, (Yogyakarta: Pustaka Ilmu, 2012), h. 5. space for expression of nationalism actualized through ideal concepts in state institutions such as judicial institutions. ${ }^{5}$

There are several legal rules governing the age limit for adults in Indonesia ${ }^{6}$. In conducting marriages in Indonesia the Act No. 16 of 2019 applies to amendments to The Act No. 1 of 1974 which must be obeyed by all Indonesian. The age limit for marriage in Indonesia is regulated in Marriage The Act No. 16 of 2019 and the Islamic Legal Compilation (KHI) ${ }^{7}$. It determines the age limit of a man and woman who will carry out a marriage contained in Article 7 Paragraph 1 which states that marriage is only permitted if the man has reached the age of 19 and the woman has reached the age of 19. With changes in the age of marriage in the law, the authors are interested in discussing in this paper with the title The Age of Marriage on The Interdisciplinary Islamic Law Perspective.

${ }^{5}$ Ratno Lukito, Hukum Sakral dan Hukum Sekuler; Studi tentang Konflik dan Resolusi dalam Sistem Hukum Indonesia (Jakarta: Pustaka Alvabet, 2008), h. 119.

${ }^{6}$ In the Civil Code article 330, Immature are those who have not reached the age of twenty-one years, and have already married. In Article 9 paragraph (1) of Islamic Law Compilation, the age limit for a child who is able to stand alone or adult is twenty-one years, as long as the child is not physically or mentally disabled or has never married. The Act no. 01 of 1974 concerning Marriage article 47 paragraph (1), Children who have not reached the age of 18 (eighteen) or have never entered into a marriage are under the authority of their parents as long as they are not deprived of their authority. And Article 50 Paragraph (1), a child who has not reached the age of 18 (eighteen) or has never entered into a marriage, which is not under the authority of the parents, is under the authority of the guardian. The Act no. 23 of 2002 concerning Child Protection article 1 paragraph (1), a Child is someone who is not yet 18 (eighteen), including children who are still in the womb. The Act no. 23 of 2003 concerning General Elections of President and Vice President article 7, Citizens of the Republic of Indonesia who are voting on 17 (seventeen) or have or have been married have the right to vote.

Compilation literally means a collection or set. In English there is the term Compilation of laws. In other terms, compilation is a collection. When related to law, compilation can be interpreted as a collection of legal material in one book. The compilation of Islamic law is the result of consensus (ijma) of scholars from various groups through a media workshop that is held nationally which then gets legalization from the power of the State. The compilation of Islamic law aims to make Islamic law acknowledged in Indonesia which means the word Islamic law must be interpreted as Islamic civil law, Budiono, Abdul Rahmad, Peradilan Agama Di Indonesia, (Malang: Bayumedia, 2003), h. 32. 


\section{The Age of Marriage According to Imam Mazhab}

The Islamic law does not regulate absolutely about the minimum age of marriage. The absence of religious provisions regarding the minimum and maximum age limit for a marriage is assumed to provide leeway for humans to regulate it. Al-Qur'an suggests that the person who will get married must be eligible. As Allah SWT states:
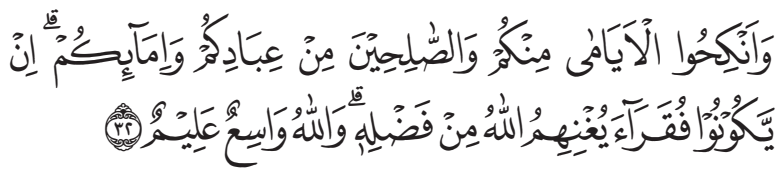

"Marry those among you who are single, or the virtuous ones among yourselves, male or female: if they are in poverty, Allah will give them means out of His grace: for Allah encompasseth all, and he knoweth all things." (QS. al-Nūr: 32)

The word (الصالحين) is understood by many scholars in the sense mentally and spiritually worthy of marriage to foster the household ${ }^{8}$. In line with the hadith of the Prophet, peace be upon him, who advocated for young people to have a marriage on the condition of ability.

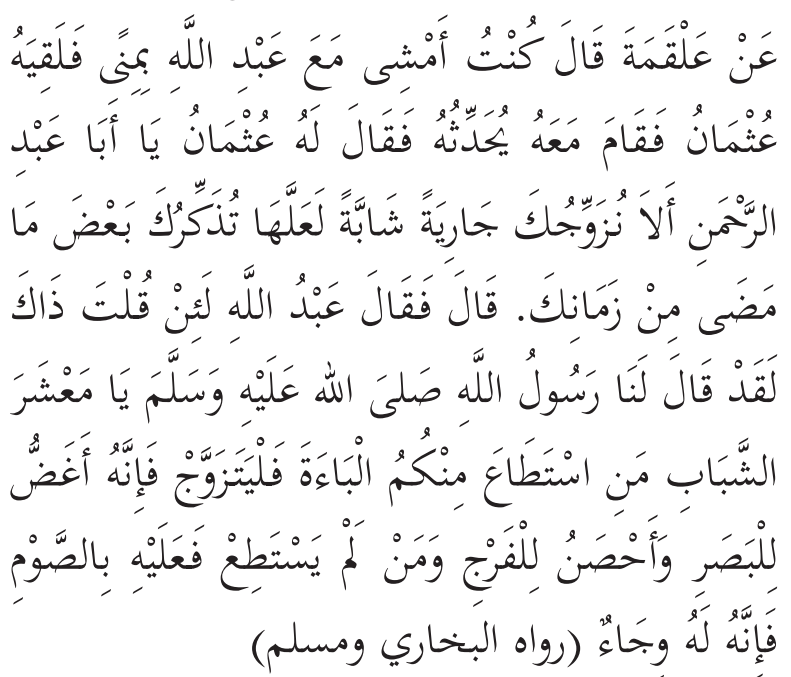

"Narrated from Alqamah r.a he said: I once went for a walk in Mina with Abdullah r.a, we met with Usman r.a who then approached Abdullah. After chatting for a while, Usman asked: "O Abu Abdurrahman, will I match you with a young woman? Hopefully it will be able to remind you of

${ }^{8}$ M. Quraish Shihab, Tafsir al-Misbah, (Jakarta: Lentera Hati, 2005), Cet. ke-4, Vol. IX, h.335. your beautiful past ". Hearing this offer Abdullah replied: What you said was in line with what the Prophet had said to us: "O youth! Who among you already has the ability of zahir and inner to get married, so let him get married. In fact, the marriage can maintain eye contact and maintain honor. So whoever is not capable, he should fast because fasting can maintain lust. (H.R Bukhari and Muslim)"

The Qur'an and the Hadith indirectly admit that maturity is very essential in marriage. The age of adulthood in figh is determined by physical signs that are general signs of age, among others, the perfect age of 15 (fifteen) for men, ihtiläm for men and menstruation in women at least at the age of 9 (nine).

By fulfilling the criteria of age it has made it possible for someone to get married. ${ }^{10}$ Therefore one's maturity in Islam is often identified by age.

If there is an abnormality or delay in physical or biological development, so that at the age where someone normally has issued semen for men or has menstrual blood for a woman but the person has not issued any signs of maturity, then the period of puberty is based on the normal age of a person spitting out signs of aging. The age of puberty between one person and another is influenced by differences in environment, geography and so forth. ${ }^{11}$

The size of maturity measured by these criteria is not rigid (relative). ${ }^{12}$ It means if the case is indeed very urgent the two brides must be married immediately, as an embodiment of the method of sadd al-zäríah to avoid the possibility of greater harm. ${ }^{13}$

The scholars differed in setting age limits for people who are considered to be mature.

\footnotetext{
${ }^{9}$ Salim bin Samir al Hadhramy, Safinah al Najah, (Surabaya: Dar al 'Abidin, t.th), h. 15-16.

${ }^{10}$ Amir Syarifuddin, Ushul Fiqh, (Jakarta: Prenada Media, 2008), Cet. ke-3, Jilid I, h. 394.

11 Direktorat Jenderal Pembinaan Kelembagaan Agama Islam, Ilmu Fiqh, (Jakarta: Departemen Agama RI, 1985), Jilid II, h. 3-4, 25.

12 Ahmad Rofiq, Hukum Islam di Indonesia, (Jakarta: Rajawali Press, 2003), Cet. ke-4, h. 78.

${ }^{13}$ Ahmad Rofiq, Hukum Islam di Indonesia..,h. 78.
} 
Syafi'iyah and Hanabilah scholars state that boys and girls are considered to be mature when they reach the age of $15 .{ }^{14}$ Whereas Hanafiyah scholars set the age for men to be considered balig if they are 18 and 17 years old for girls. ${ }^{15}$

\section{Marriage as an Adult Act}

Marriage in general for humans is something that is highly expected and prepared. It is not uncommon for humans to find various information about marriage by asking parents or friends, reading books, or being provided with various information about marriage through courses.

Marriage is an event that can take place after consideration both rationally and emotionally or mentally. Besides being thought and accepted by common sense, all marriage preparations are the mental preparation of the prospective spouse. This mental preparation starts from the simplest thing, which is to know and understand the couple and meaning of marriage. In the preparatory stages of marriage, fostering social relations, romantic and harmonious, is important and required to be undertaken for people who are already mukallaf (a person obligated by law to discharge a legal duty). The requirements for the mukallaf are people who are well-informed, capable and able to carry out taklif (the burden of an order or prohibition).

The ability is basically a counterpart to rights. Someone who has been able to get married means he is someone who is able to exercise the rights of his wife or husband. Conversely, those unable to get married are who have not been able to exercise the rights of their wife or husband. ${ }^{16}$

\footnotetext{
${ }^{14}$ Muhammad Jawad Mughniyyah, Al-Ahwal al-Syakhsiyyah, (Beirut: Dar al-'Ilmi li al-Malayin, t.th), h. 16.

${ }^{15}$ Muhammad Jawad Mughniyyah, Al-Ahwal al-Syakhsiyyah, h. 16 .

${ }^{16}$ Regard of rights, this ability is sometimes a legal condition of a marriage contract and sometimes it is not a condition of the legality of a marriage contract, depending on the bride and groom whose religion is given rights, due to the marriage ties. If the prospective husband or wife is willing with the prospective wife or husband who cannot carry out their obligations after the
}

The ability can be broadly classified in: ${ }^{17}$

\section{Physical and spiritual abilities}

Islam does not explicitly set the age limit of someone who has been able to marry and who has not been able to marry. The Qur'an and Hadith are only stipulated by signs. It is up to the Muslims to set an appropriate age limit for marriage in accordance with the predetermined signs, and also to adapt to local conditions where the law will be passed. The signals are:

a. Khitab (commands and prohibitions) in the Qur'an and hadith is addressed to the believers, relating to marriage. The signs of the believer are as stated in the hadith:

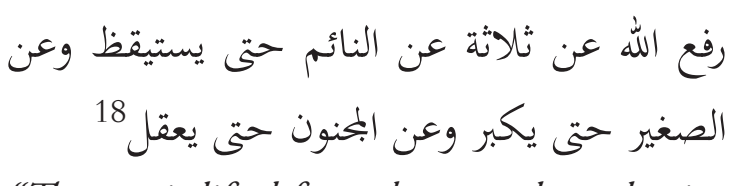

"The pen is lifted from three people: a sleeping person until he awakens, a child until he becomes an adult, and an insane person until he regains his sanity."

Based on the hadith above, there are three kind of signs of believers namely people who wake up from sleep, people who have been baligh and healthy, not insane.

b. Furthermore, the hadith explains that those ordered to marry are people who have aged so that they are able to have marital relations, to obtain offspring based on the traditions:

marriage contract, the ability is not a condition for the validity of the marriage contract. Conversely, if a prospective husband or wife is not willing with the ability of other parties, the capability is a legal requirement for a marriage contract. Therefore a marriage contract for a man who is impotent with a woman is legitimate, if the woman is willing, if she does not obtain the right to mention her husband after the marriage contract takes place later. See Kamal Mukhtar, Asas-Asas Hukum Islam Tentang Perkawinan, (Jakarta: Bulan Bintang, 1993), Cet. ke-3, h. 39.

17 Kamal Mukhtar, Asas-Asas Hukum Islam Tentang Perkawinan.., h. 39-43.

${ }^{18}$ Abu Dawud Sulaiman bin al-'Asy'as al-Sajastani, Sunan Abi Dawud, "Kitab al-Hudud" (Beirut: Dar al-Fikr, t.th), Juz IV, h. 141. Hadis diriwayatkan dari Musa bin Ismail telah menceritakan kepadaku Wahid dari Khalid, dari Abi ad-Duha dari Ali ibn Abi Talib, Abu Isa Muhammad bin Isa bin Surah, Sunan al-Tirmizi, "Kitab al-Hudud: Ma Ja’a fi Man la Yajibu Alaihi al-Hadad" (Makalah: Maktabah at-Tijariyah, t.t), Juz III, h. 24. 


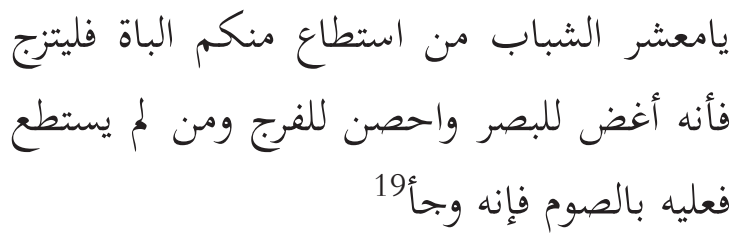

"Which of you already has the natural ability of things ba'a ${ }^{20}$ go get married, because marriage is to hold eyesight and keep the genitals. And, whoever has not been able to do it, he should fast because actually fasting can be a shield (turmoil of sexual desire)".

Al-Syabāb means youth. ${ }^{21}$ According to scholars, youth is around the age of 16 to 30. Al-Syafi'i argued that al-Shabab is a person who has grown to a perfect 30 years old. Al-Qurtubi in al-Fahm said that alShabab is a person who is aged 16 to 30 and for ages 30 years and above is called kahal. In the opinion of al-Zamakhsari, al-Syabab is a person who are 20 up to 30 years old. In the book Jawahir, Ibn Syas al-Maliki said that the youth limit is up to the age of 40 years. Meanwhile, according to al-Nawawi, al-Syabab is not only a person who is old until the age of 30 years, but what is said by al-Syabab is to reach the age of 40 years, and above that is called a shaykh. ${ }^{22}$

Al-Ba'ah means provision. ${ }^{23}$ The implied meaning of the hadith about the marriage proposal above is that marriage should be

${ }^{19}$ Imam Muslim, Sahih Muslim, "Kitab al-Nikah" (Bairut: Dar al-Fikr, t.th), Jilid I, h. 583. Hadis diriwayatkan oleh Imam Muslim dari Yahya at-Tamimi, dari Abu Bakr bin Abi Syaibah dan Muhammad bin al-'Ala' al-Hamdani, kesemuanya dari Muawiyah, dari al-A'masy dari Ibrahim dari 'Alqamah; Al-Bukhari, Shahih.....,"Kitab al-Nikah" "Bab al-Targhib fi an-Nikah Qaulihi Ta'ala fa Ankihu ma Thaba lakum min anNisa', VI: 117, hadis No. 1 Hadis diriwayatkan dari Sa'id IBnu Abi Maryam, Lihat juga dalam Abi Isa Muhammad bin 'Isa bin Aurah, Sunan at-Tirmizi. "Kitab al-Nikah:, Juz III, h. 391.

${ }^{20}$ Al-ba'ah can mean living or jima' (intercourse). If ba'ah is defined as the ability to have intercourse, then if someone, whether male or female, is able to do it, in the sense of being biologically prepared, then it is recommended to get married immediately. If interpreted as a living it is possible that many people who have reached maturity in terms of age cannot fulfill it.

${ }^{21}$ Ibnu Hajar Al-Asqalani, Fath Al-Bari bi Syarh Shahih AlBukhari juz XIV, (Mesir: Dar al-kutub al-Ilmiyyah, t.th), h. 292.

22 Syarh al-Nawawi ala Muslim, Juz V, h.70.

${ }^{23}$ Syarh al-Nawawi ala Muslim, Juz V, h. 71. prepared carefully both in material and non-material terms. The word al-Ba'ah in the editorial of the hadith refers to two meanings, namely, (1) Al-Muzairi said alba'ah originally meant the desire to marry a woman, (2) al-Nawawi said that the word al$b a^{\prime} a h$, according to the scholars, has several meanings including: according to linguists, al-ba'ah means jima' (intercourse), then the intention of al-Ba'ah in this hadith is a person who has been able to make jima' and is able to provide for physical and spiritual support. As for those who do not have the ability in both cases, they should perform fasting to relieve lust and block bad feelings and to fortify themselves from the crime of adultery. ${ }^{24}$

Falyatazawwaj means to get married. ${ }^{25}$ It shows the command to get married which is at the same time accompanied by the marriage law in accordance with the indications as well as the situations and conditions possessed by a young man who functions as a book in this hadith. When viewed from the perspective of Islamic Jurisprudence, marriage laws vary according to the situation and existence of a person. For anyone who already has the ability physically and spiritually, the law of marriage becomes obligatory to avoid immoral acts and adultery. However the law of marriage will be a sunnah for people who have only physical or spiritual abilities. In situations and conditions of a person who has no ability at all to get married both physically and mentally, then the law of marriage becomes haram. While other laws of marriage are makruh and mubah. ${ }^{26}$

The hadith on the suggestion of marriage implies the implied meaning that Islam forbids a person to be forever single. For those who already have the ability and

\footnotetext{
${ }^{24}$ Syarh al-Nawawi ala Muslim, Juz V h. 71.

${ }^{25}$ Ibnu Hajar Al-Asqalani, Fath Al-Bari bi Syarh Shahih AlBukhari, Juz XIV, h. 294.

${ }^{26}$ Sayyid Sabiq, Fiqh al-Sunnah, Terj. Muhammad Thalib, (Jakarta: Al-Ma’arif, 1980), h. 22-26.
} 
willingness, they are told to immediately carry out marriage.

Both of the above traditions can be used as a basis by the government to determine the most appropriate age to carry out a marriage so that it can achieve its goals. In the meantime, the government can stipulate provisions relating to the marriages of people whose souls or minds are damaged.

\section{The ability to provide a living}

A husband is obliged to provide for his wife, his children and other family members. Among them are mentioned in the word of God.

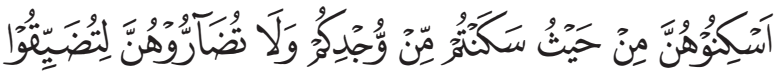

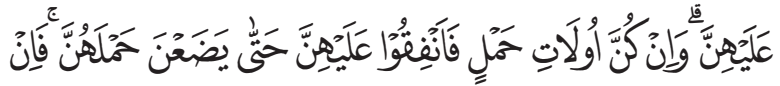

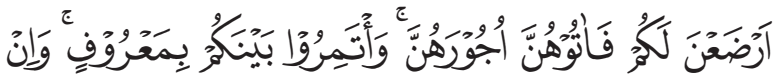

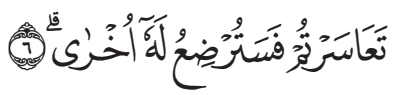

"Let the women live (in iddat) in the same style as ye live, according to your means: Annoy them not, so as to restrict them. And if they carry (life in their wombs), then spend (your substance) on them until they deliver their burden: and if they suckle your (offspring), give them their recompense: and take mutual counsel together, according to what is just and reasonable. And if ye find yourselves in difficulties, let another woman suckle (the child) on the (father's) behalf." (Q.S. Al-Talāq (65): 6).

Therefore, Allah SWT forbids those who are unable to provide for their marriages. It is an obligatory for him to preserve himself from being prohibited by Religion. As Allah SWT states:

ق.

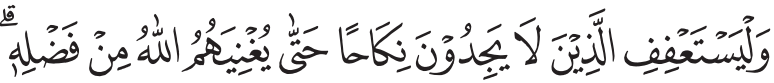

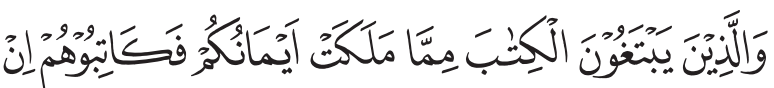

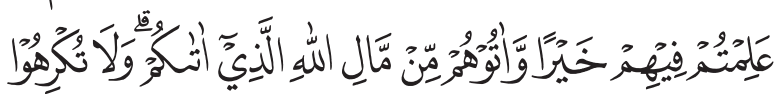

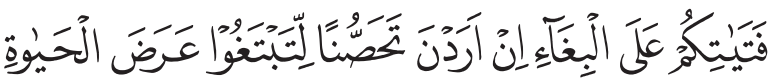

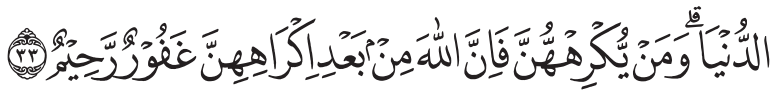

"Let those who find not the wherewithal for marriage keep themselves chaste, until Allah gives them means out of His grace. And if any of your slaves ask for a deed in writing (to enable them to earn their freedom for a certain sum), give them such a deed if ye know any good in them: yea, give them something yourselves out of the means which Allah has given to you. But force not your maids to prostitution when they desire chastity, in order that ye may make a gain in the goods of this life. But if anyone compels them, yet, after such compulsion, is Allah, Oft-Forgiving, and Most Merciful (to them)." (Q.S. Al-Nūr (24): 33).

3. The ability to socialize and to manage the household

The ability to get along well from the prospective bride to row the household is a condition of a marriage that will achieve the goals. Therefore God requires the husband to treat his wife well. As Allah SWT states:

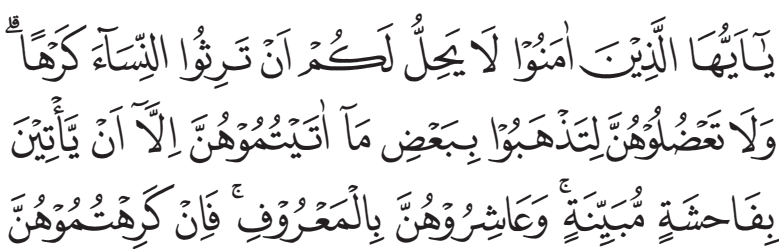

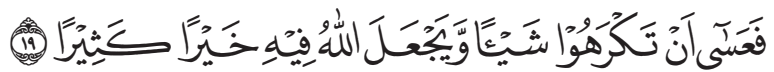
"O ye who believe! Ye are forbidden to inherit women against their will. Nor should ye treat them with harshness, that ye may Take away part of the dower ye have given them,-except where they have been guilty of open lewdness; on the contrary live with them on a footing of kindness and equity. If ye take a dislike to them it may be that ye dislike a thing, and Allah brings about through it a great deal of good." (Q.S. Al-Nisā’ (4): 19).

\section{The Age of Marriage on Interdisciplinary Islamic Law Perspective}

In discussing maturity, we cannot limit ourselves to just one or two scientific fields, but are forced to conduct interdisciplinary studies because maturity is used by almost all fields of social science, such as: sociology, legal studies, political science, economics and religious 
studies which becomes a matter of principle and decisive maturity. ${ }^{27}$

Diversity in determining the age limit of maturity is due to the absence of benchmarks that can be used accurately to determine the limits of human maturity. However it is not always the right measure because maturity is a condition where a person has reached the level of maturity in thinking and acting, while the level of maturity, in each person, is different. As an opinion says that it might be up to the end of his life, humans have never experienced maturity because maturity is not always directly proportional to age. Indeed, not all laws and regulations state explicitly the limits of maturity.

However, by determining the age limit for a particular legal act, it is actually maturity that is being measured. For example in some laws only include age restrictions for those who are called children, so above that age limit must be considered as an adult, or the law allows someone to do a certain act after exceeding the specified age limit. All of these arrangements are ultimately aimed at the intent and understanding of maturity. The ability to think conceptually based on norms and value systems makes human civilization continue to develop rapidly.

In relation to the pattern and level of human civilization, there is a condition in human beings that is always associated with mental quality and personal maturity, these conditions are adulthood. Maturity is always a measure in every action and responsibility that is carried out, so that maturity becomes an essential factor in every social interaction, both of which have legal consequences and are limited to the scope of social relations. ${ }^{28}$

\section{The Age of Marriage on Psychological Perspective}

Psychology notices that underage marriages are not just age restrictions on humans. The

\footnotetext{
${ }^{27}$ Jusuf, Sudut Pandang Sosiologi Fungsi Keluarga, (Surabaya: PT. Sinar Sejahtera, 2004), h 39.

${ }^{28}$ Jusuf, Sudut Pandang..., h. 53.
}

initial marriage is more accurately said as a young marriage. This reason relates more to the problem of the non-physical development side, both biological and psychological development (emotional, cognitive and social).

The concept of psychology does not explicitly mention the age limit of marriage, but the period of human development requires sexual development that leads to sexual relations with the opposite sex who are loved, and seen as friends sharing joy and sorrow. The period in which the actual development of sexual genitality occurs is an adult sex encouragement. Thus it can be understood that the concept of psychology related to marital age is the fulfillment of adult development criteria.

In most ancient cultures, adult status is achieved when the growth of puberty and the maturity of the child's genital organs is achieved and able to produce. In this case Indonesian culture assumes that a person is adult, if he/she is married, even though he is not yet 21 years old.

Meanwhile, psychologists generally set adulthood around the age of 20 years as early adulthood and last until the age of $40-45$ years, and mid-adulthood lasts around $40-45$ years to around 65 years and the old age lasts around 65 years up to die. ${ }^{29}$

A person during adulthood, the social and personal relation of an individual becomes more extensive and complex. In this age, individuals enter a broader role in life. Patterns and behavior will have changes caused by life events related to family and work. During the adult period people specifically involve themselves in career, marriage and family life.

A marriage is ideally carried out by male and female couples who have maturity, both in terms of biological and psychological aspects. Biological maturity is when someone already has maturity both in terms of age and physical.

${ }^{29}$ Fieldman Robert S, Understanding Psychology (New York: McGraw Hill, 1996), h. 47. 
While psychological maturity is when someone has been able to control his emotions and can be thought well and put problems in accordance with subjective-objective circumstances.

The personal maturity is the one who has reached a level of maturity, as well as developing the function of the mind and developing emotions and is able to position themselves to overcome weaknesses in facing challenges both themselves and from others. Personal maturity is very big influence for married couples. The immature husband and wife in personal terms in building marriages will often quarrel, bicker, and even lead to divorce. ${ }^{30}$

\section{The Age of Marriage on Sociological Perspective}

Meanwhile, from a sociological perspective, adolescence can be interpreted as a period of integration of a person with adult society. Integration in society (adults) has many effective aspects, more or less related to puberty. Including the striking intellectual change, the intellectual transformation that is typical of the way of thinking of adolescents enables it to achieve integration in the social relations of adults which is in fact a common characteristic of the developmental period. ${ }^{31}$

Marriage as an institution, viewed from a sociological perspective is a family institution that not only guarantees human survival but also social stability and a dignified existence for men and women in their society. Therefore, a marriage institution built by a couple that is psychologically lacking maturity, can cause disharmony in society, as can be seen from a phenomenon of abandoned children.

Regarding early marriage factors and their impact on negligence of children, legally, this clearly violates the Act of the Republic of Indonesia No. 35 of 2014 concerning

\footnotetext{
${ }^{30}$ Jusuf, Sudut Pandang..., h. 27.

31 Achmad Mubarok. Psikologi Keluarga dari Keluarga Sakinah Hingga Keluarga Bangsa, (Jakarta: Bina Reka Pariwara, 2005), h. 12.
}

Amendments to The Act No. 23 of 2002 concerning Child Protection which at least covers, first ; children's right to education. The case of early marriage shows the child does not continue school, second, the right of the child to think and express, third, the right of the child to express his opinions and be heard, fourth, the right of the child to rest and utilize free time, hanging out with peers playing, expressing and being creative, and fifth, the child's right to get protection. ${ }^{32}$

\section{The Age of marriage on Biological Perspective}

The condition of people who want to get married or have a family is highly recommended to maintain health so that they are physically and mentally healthy. The psychological ill, for example a wife who is depressed by her husband, or vice versa, will have very direct implications on the growth of children, both in the form of attitude and behavior. While physical health includes health in the sense that the person does not have a disease (especially infectious diseases) and is free from hereditary diseases.

Regardless of the ideal age limit that has the potential to support reproductive health, what can be done is to familiarize people to live in a healthy pattern as a prevention alternative. Improved quality of life, nutrition, and knowledge, are factors that encourage menstruation in daughters at an earlier age (getting younger). Therefore, the community needs to be equipped with adequate knowledge about reproductive health so that by increasing insight and broad knowledge it can influence women to choose to marry at a proportional age.

Some health experts claim that marriages of young couples for women, especially under the age of 17 are at risk of cervical cancer. ${ }^{33}$

Cervical cancer is the most cancer in Indonesian women besides breast cancer. In the early stages

\footnotetext{
${ }^{32}$ Achmad Mubarok. Psikologi Keluarga..., h. 54.

${ }^{33}$ Achmad Mubarok. Psikologi Keluarga..., h. 37.
} 
of cervical cancer, it does not cause complaints or clinical symptoms. At an advanced stage the symptoms are vaginal discharge that smells and are mixed with blood, bleeding outside menstruation, bleeding after intercourse, pelvic pain or unable to urinate. Cervical cancer is found in the pre-cancer stage, so the chance of recovery is huge. Vaccination has been recommended by IDAI (Indonesian Pediatric Society/IPS) and HOGI (Indonesian Society of Gynecologic Oncology/INASGO) to be given to young women from the age of 10 through vaccination with early detection.

Women who can be categorized as mature, the cervix is anomically able to function normally, supported by a mature psychiatric factor to be ready for pregnancy and childbirth. Psychologically immature women are still sensitive to pregnancy, anxiety, and fear of giving birth. Even the impact on infant or maternal mortality rates, it is caused by the famales who are not ready to give birth. ${ }^{34}$

\section{Conclusion}

The minimum age for marriage in The Act No. 16 of 2019 on amendments to The Act No. 1 of 1974 concerning Marriage is to be equalized between men and women at the age of 19 years. At this age, men and women are still classified as adolescents, in the process of growing up in reaching biological, sociological, and psychological maturity. The age of marriage is an area of ijtihadiyah so that it is always open to change when conditions, society, time and place have demanded the change. In this regard, the authors offer to do the reconstruction again of these provisions to be 19 years for women and 21 years for men. This is based on consideration of aspects of biological, psychological, and sociocultural maturity. With the age of 21 years, men are considered to reach maturity in their attitude, eligible to act, and responsible for their actions. Whereas a 19 -y e ar-old woman is considered to be an adult and able to run a domestic life.

\footnotetext{
${ }^{34}$ Sutan Marajo Nasaruddin. Problematika Seputar Keluarga Dan Rumah Tangga, (Bandung: Pustaka Hidayah, 2001), 67.
}

Under the theory of maquishid syariah, at least in relation to the four basic elements protected by religion, as the initial purpose of legal inquiry which are the maintenance of offspring, souls, intellect, and property in the family.

\section{References}

Ali, Ahmad, Menguak Realitas Hukum: Rampai Kolom dan Artikel Pilihan dalam Bidang Hukum, Jakarta: Kencana, 2008.

Andiko, Toha. "Pembaruan Hukum Keluarga di Dunia Islam (Analisis Terhadap Regulasi Poligami dan Keberanjakannya dari Fiqh)", Nuansa: Jurnal Studi Islam dan Kemasyarakatan, Vol. 12, No. 2, Desember 2019.

Budiono, Abdul Rahmad, Peradilan Agama di Indonesia, Malang: Bayumedia, 2003.

Chalil, ZakiFuad. "Tinjauan Batas Minimal Usia Kawin; Studi Perbandingan Antara Kitab-Kitab Fikih dan Undang-Undang Perkawinan di Negara-Negara Muslim," dalam Mimbar Hukum VII, No. 26, 1996.

Coulson, N.J. A History of Islamic Law, Edinburhg; Edinburgh University Press, 1991.

Cummack, Mark E. "Islamic Law in Indonesia's New Order", International and Comprative Law Quarterly Journal, Vol. 38, Januari, 1989.

Dahlan, Abdul Aziz dkk (ed). Enskilopedi Hukum Islam, Jakarta: PT. Ichtiar Baru Van Hove, 2001, Cet. ke-1.

Dahlan, Abdul Rahman. UshulFiqh, Jakarta: Amzah, 2010.

Departemen Agama Republik Indonesia, AlQur'an dan Terjemahnya, Surabaya: CV. Jaya Sakti, 1997.

Farid, Miftah. 150 Masalah Nikah dan Keluarga, Jakarta: Gema Insani, 1999.

Fuad, Mahsun. Hukum Islam Indonesia; Dari Nalar Partisipatoris hingga Emansipatoris, Yogyakarta: LKiS, 2005.

Hanafi, Yusuf, Kontroversi Perkawinan Anak Dibawah Umur Child Marriage Perspektif Fikih Islam, Ham Internasional, Dan Undang- 
Undang Nasional, Bandung: Mandar Maju, 2011.

Hasan, Syaikh, Ayyub, Fikih Keluarga, Jakarta: Pustaka Al-Kautsar, 2006.

Lukito, Ratno. Hukum Sakral dan Hukum Sekuler: Studi Tentang Konflik dan Resolusi dalam Sistem Hukum Indonesia, Jakarta: Pustaka Alvabet, 2008.

Mardani, Hukum Perkawinan Islam di Dunia Islam Modern, Yogyakarta: Graha Ilmu. 2011.

Muthmainnah, Yulianti. "Perempuan dalam Budaya Pernikahan di Indonesia Membaca Ulang RUU Hukum Materiil Peradilan Agama Bidang Perkawinan" Majalah Swara Rahima, Ed. 36 Juni 2010.

Nasaruddin, Sutan Marajo. Problematika Seputar Keluarga Dan Rumah Tangga, Bandung: Pustaka Hidayah, 2001.
Fieldman, Robert S. Understanding Psychology, New York: McGraw Hill, 1996.

Sabiq, Sayyid, Fiqh al-Sunnah, Terj. Muhammad Thalib, Jakarta: Al-Ma'arif, 1980.

Shihab, M. Quraish. Tafsir al-Misbah, Jakarta: Lentera Hati, 2005, Cet. ke-4, Vol. IX

Syamsu, Andi Alam, Usia Ideal memasuki Dunia Perkawinan; Sebuah Ikhtiar Mewujudkan Keluarga Sakinah, Kencana Mas;Bandung, 2005.

Taimiyah, Ibn. Al-Siyasah al-Syar'iyyah, Mesir: Dar al-Kitab al-'Arabi, 1969.

Tim Pengarusutamaan Gender, Pembaruan HukumIslam: Counter Legal Draft Kompilasi Hukum Islam, Jakarta: Depag RI, 2004.

Wajidi, Farid dan Assegaf Cici Farikha, Yogyakarta: Yayasan Bentang Budaya, 2009. Cet ke-1. 